\title{
Small areas and small plants: Updates on Antarctic bryophytes
}

\author{
Júlia V. Mundim* (D), Tamara S. Dantas ${ }^{1}$ (D), Diego K. Henriques ${ }^{1}$ (D), Jair E. Q. de Faria-Júnior ${ }^{2}$ (D), \\ Dafne A. A. dos Anjos ${ }^{1}$ (1), Juçara Bordin ${ }^{3}$ (1), Paulo E. A. S. Câmara ${ }^{1}$ (D) and Micheline Carvalho-Silva'
}

Received: September 28, 2020

Accepted: December 19, 2020

\begin{abstract}
Snow Island is part of the South Shetland Archipelago in Antarctica. Most of its surface is permanently covered by snow, yet it has an important paleobotanical site. There are no protected areas on the island and no recent data regarding its vegetation. This study aimed to collect and identify fresh samples of bryophytes from President Head Peninsula of Snow Island. Samples were collected during the summers of 2015 and 2018. Among the 24 bryophyte species identified in this work, 19 are new occurrences for Snow Island, bringing the total known for the island to 29 species. The most diverse family is Pottiaceae, with four species of two genera, followed by Bryaceae and Polytrichaceae, with three species each. The results show that the diversity of mosses on Snow Island is greater than previously reported. We here demonstrated the region's importance and the $190 \%$ increase in Snow Island species number. This study also updated the Antarctic distribution of some species.
\end{abstract}

Keywords: Bryophyta, flora, Maritime Antarctica, new occurrence, South Shetlands

\section{Introduction}

Antarctica is the most distant and isolated continent, and is considered the driest and coldest region on the planet (Bargagli 2005; Cassano 2013). It is inhabited by extremophile organisms that are able to establish themselves and survive the harsh conditions (Longton \& Holdgate 1979). These characteristics make Antarctica a unique place for the development of scientific research in diverse areas such as environmental science and biodiversity (Câmara et al. 2017). The continent itself has an area of over 14 million $\mathrm{km}^{2}$, of which only $0.3 \%$ is ice free during the summer season and represents potential substrata for local vegetation (Fox \& Cooper 1994). The South Shetlands is an archipelago that covers an area of $3687 \mathrm{~km}^{2}$. It comprises 11 main islands and is located north of the Antarctic Peninsula.
According to Lewis-Smith (1984) and Ochyra et al. (2008), the archipelago belongs to the northern Maritime Antarctica geobotanical zone characterized by a cold moist climate with milder temperatures during summer and annual precipitation ranging 350-550 mm, mostly concentrated as rain during the warmer season. This zone also holds greater botanical diversity than other Antarctic regions zones (Ochyra et al. 2008).

Antarctic vegetation is predominantly cryptogamic, with 116 species of bryophytes, 500 species of lichens and three species of flowering plants having been reported for the continent (Ochyra et al. 2008; Ellis et al. 2013a; b; Sollman 2015; Câmara et al. 2019a). Although the bryophyte flora of Antarctica has been the focus of various researchers in the past, and many aspects of its composition have been elucidated (Putzke \& Pereira 1990; Bednarek-Ochyra et al.

1 Universidade de Brasília, 70910-900, Brasília, DF, Brazil

2 Jardim Botânico de Brasília, 71680-001, Brasília, DF, Brazil

3 Universidade Estadual do Rio Grande do Sul, 95520-000, Osório, RS, Brazil

* Corresponding author: mundimjv@gmail.com 
2000; Ochyra et al. 2008), there have been few efforts to investigate the genetic diversity and true identity of many of the taxa occurring on the frozen continent.

Recent studies regarding moss diversity and biogeography integrating a molecular approach have shown that bryophytes, especially mosses, have much yet to be discovered (Biersma et al. 2017; 2018a; b; Câmara et al. 2018; 2019a; b). Recent sampling and site-oriented investigations have also demonstrated that moss species distributions remain a subject of discussion and that the South Shetland Archipelago, which bears most of the ice-free area in Maritime Antarctica, may hold greater diversity than that described in traditional literature (Câmara et al. 2017; Henriques et al. 2018; Câmara et al. 2020). Although the flora of Antarctica has been published, new occurrences continue to be found. In addition, treatments of local flora are almost non-existent, and are known to be fundamental, as they allow for better monitoring of changes that vegetation may be experiencing in the face of climate change.

Climate change has a strong impact in Antarctica, such as changes in the original composition of organisms (Amesbury et al. 2017; Robinson et al. 2018), disappearance of species, competition with new species and decreased availability of habitats and microhabitats (Hogg et al. 2006, Bokhorst et al. 2008, Glime 2017).

According to Turner et al. (2009), climate change is more perceptible in the region of the South Shetland Archipelago and the Antarctic Peninsula, which are areas of high concentrations of mosses and lichens (Ochyra et al. 2008). Even so, studies that monitor vegetation and local floras are scarce.

Snow Island is part of the South Shetland Archipelago. It is located southwest of Livingston Island and separated from it to the northeast by the Morton Strait. Snow Island has an area of approximately $162.57 \mathrm{~km}^{2}$, with its surface almost completely covered by snow during most of the year, and its highest point is $305 \mathrm{~m}$ a.s.l. (López-Martínez et al. 2016). President Head Peninsula is located in the northeast of Snow Island and is an extremely rich geological and paleobotanical site - it is considered an important source of data for understanding the expansion and paleobotany of Antarctica (Phillipe et al. 1995; Cantrill 1997; Cantrill et al. 1998). Studies have characterized the paleoenvironment and the past flora of the Peninsula, especially regarding the Mesozoic, demonstrating the Island's connections through palynological and biostratigraphical data with the Byers Peninsula group of Livingston Island (Duane 1996; Torres et al. 1997; Cantrill et al. 1998). Other studies have also demonstrated the Early Cretaceous flora connection among Australia, South America and Antarctica through paleopalynological data, highlighting the scientific importance of Snow Island (Cantrill 1997; Cantrill et al. 1998).

Although Snow Island has its scientific relevance, it has no protected areas, not even an Antarctic Specially Protected Area (ASPA) or an Antarctic Specially Managed
Area (ASMA). Even though several studies have revealed the fossil flora (Cantrill 1997; Torres et al. 1997; Cantrill et al. 1998), there are no current projects focusing on the Island's extant flora, especially the current bryoflora. The only available information regarding liverworts from Snow Island is a list produced by Bednarek-Ochyra et al. (2000). The mosses of the Island were treated by Ochyra et al. (2008), who reported only ten species collected on President Head Peninsula.

Due to its scientific relevance, and knowing that recent studies reported greater diversity than other areas already surveyed in Antarctica, we collected and studied fresh material from President Head Peninsula with the aim of increasing and updating knowledge of the botanical diversity of Snow Island. Thus, we provide an updated list of species along with an identification key and illustrations.

\section{Materials and methods}

Field expeditions to Snow Island occurred during the Antarctic summers of 2015 and 2018, in snow free areas on President Head Peninsula (Fig. 1). Collections were made according to Yano (1984), and vouchers were deposited in herbarium UB (Universidade de Brasilia). Samples were observed and studied under a stereomicroscope (Leica EZ4 HD) and an optical microscope (Leica DM 750). Semipermanent slides were made using Hoyer solution (Anderson 1954) to investigate taxonomically useful structures. Images of important structures and details were taken with a camera (Leica $170 \mathrm{HD}$ ) coupled to an optical microscope (Leica DM 750). Identifications followed Ochyra et al. (2008) and the classification system adopted was that of Goffinet et al. (2009). All terminology followed Magill (1990). Voucher information is available in List S1 in supplementary material. The list presented here combines the data resulting from our collections with the list of Ochyra et al. (2008).

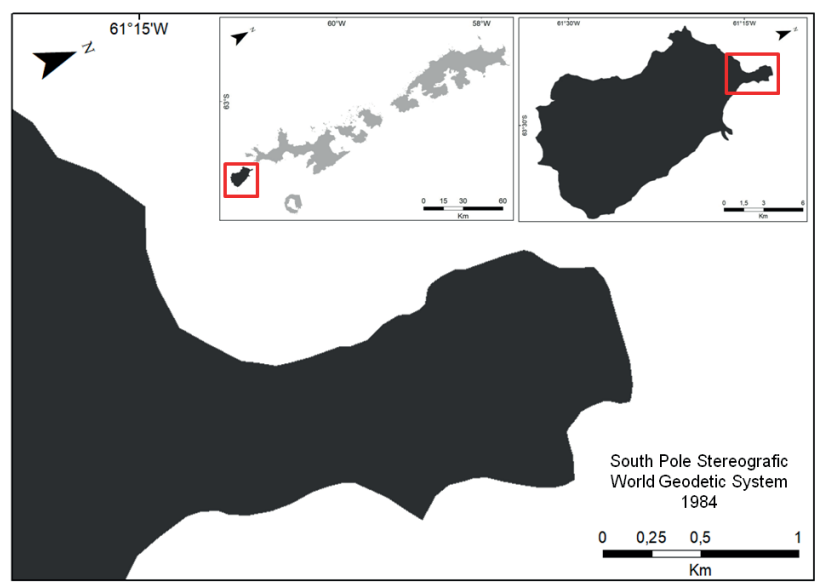

Figure 1. Map of President Head Peninsula, Snow Island, South Shetlands, Antarctica. The indicated region represents Snow Island and President Head Peninsula. 


\section{Results and discussion}

One hundred and eighty-five samples were collected on Snow Island during the Antarctic summers of 2015 and 2018, representing a total of 24 species of bryophytes distributed among 16 genera and 12 families. Among the 24 species (Tab. 1), 19 are new occurrences for Snow Island. The most diverse family is Pottiaceae, with four species in two genera, followed by Bryaceae and Polytrichaceae, with three species each.

The considerable number of new moss occurrences found by the present study can be explained by the lack of detailed studies focused on Snow Island. President Head Peninsula is the main ice-free area of the Island and past studies mainly focused on just part of it. The present research surveyed the peninsula and its surrounding areas, wherever soil and rocks were available for examination. Even though the focus of our work was to perform a broader sampling of the Island, we were limited by logistics and weather conditions. Nevertheless, 19 new occurrences were found.

Our results are congruent with recent local studies of Antarctic flora (Câmara et al. 2017; Henriques et al. 2018) and revealed that the number of species occurring in Snow Island was underestimated in previous works. The diversity of local bryophytes in Antarctica is still worth investigating. Table 2 provides information on the distribution of all species of bryophytes found to date on Snow Island, including those cited by Ochyra et al. (2008), but not collected by the present study.

The following is an identification key based on the updated list of species occurring on Snow Island. Included in the key are 19 newly recorded species found by the present study and the 10 other species already mentioned by Ochyra et al. (2008).

\section{Key to the mosses of Snow Island (Fig. 2)}

1. Plants pleurocarpous, stems prostrate, forming wefts or mats ……………………………………………………………….. 2

1. Plants acrocarpous, stems erect, forming tufts or cushions .......................................................................................... 8

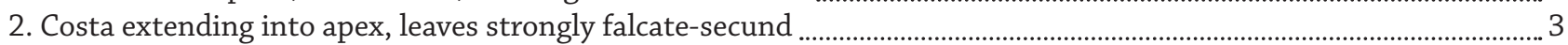

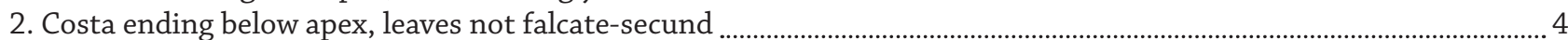

3. Leaves with alar cells forming an isodiametric group ............................................................ Sanionia georgicouncinata

3. Leaves with alar cells forming a triangular group .................................................................................. Sanionia uncinata

4. Costa frequently short and branched near the leaf base ..................................... Drepanocladus polygamus (Fig. 2K-L)

4. Costa extending for $1 / 2$ to $3 / 4$ of leaf length, not branched ………………………………………………………….... 5

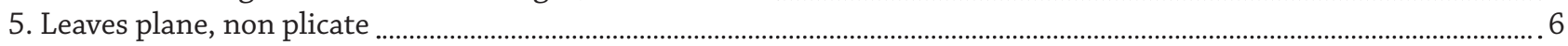

5. Leaves strongly concave, plicate ............................................................................................................................... 7

6. Alar region undifferentiated .................................................................................................... Warnstorfia fontinaliopsis

6. Alar region differentiated ................................................................................................................ Warnstorfia sarmentosa

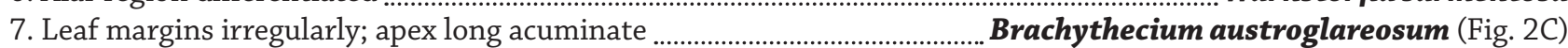

7. Leaf margins plane; apex short, acuminate .................................................. Brachythecium austrosalebrosum (Fig. 2D)

8. Leaf costa absent

8. Leaf costa present

9. Leaves lanceolate to ovate-lanceolate; leaf margins entire ................................................................. Andreaea regularis

9. Leaves panduriform to ovate-spatulate or oblong, leaf margins crenate or dentate at base .................. Andreaea gainii

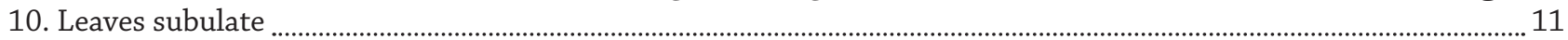

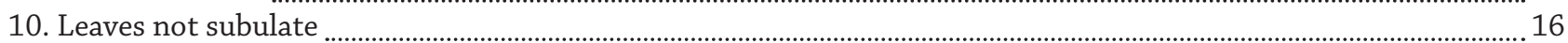

11. Subula never tubulose, shoulder well marked ……………………………………………….... Bartramia patens (Fig. 2A-B)

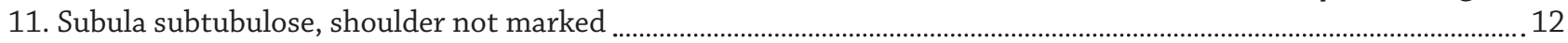

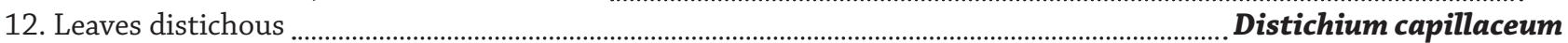

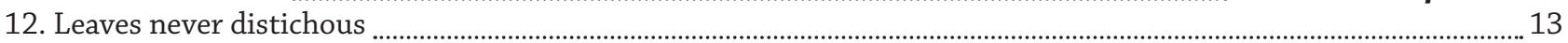

13. Large central strand in transverse cross section of the stem, leaves abruptly tapering to a subula

Ditrichum hyalinum

13. Small central strand in transverse cross section of the stem, leaves gradually tapering to a subula

14. Costa broad, occupying $1 / 3$ or more of the leaf base, excurrent

Chorisodontium aciphyllum

14. Costa narrower, occupying $1 / 4$ or less of the leaf base, subpercurrent or percurrent 15

15. Costa percurrent; cross section of costa showing a strong dorsal stereid band and a weaker (or absent) ventral one; ventral epidermal cells long, rectangular to linear in the subula.

Hymenoloma antarcticum

15. Costa subpercurrent; cross section of costa showing weak stereid bands on both surfaces; ventral epidermal cells short, rectangular to rounded in the subula Hymenoloma grimmiaceum

16. Cell walls thickened or ornamented with papillae or mamillae

16. Cell walls never thickened or ornamented with papillae or mamillae

17. Leaves without $C$-shaped papillae, lanceolate to long lanceolate; costa with two stereid bands in cross section 
17. Leaves with C-shaped papillae, leaves ovate, oblong-lanceolate; costa with one or more stereid bands in cross section

18. Leaves ovate-elliptic to ovate-lingulate; costa excurrent, ending in a hyaline hair-point

Syntrichia magellanica (Fig. 2X, Z)

18. Leaves oblong-lanceolate to lingulate-spathulate; costa percurrent, rarely short-excurrent, hyaline hair-point absent

19. Leaves short acuminate; leaf margins dentate or serrate, crenate at the apex

Syntrichia filaris (Fig. $2 \mathrm{~W}$ )

19. Leaves long acuminate; leaf margins entire throughout Syntrichia saxicola (Fig. 2Z)

20. Ventral lamellae present in leaf cross section

20. Ventral lamellae absent in leaf cross section ...

21. Leaf margins entire; apex hyaline and piliferous

21. Leaf margins serrate; apex never piliferous

22. Leaves crowded in upper part of the stem; leaves ending in a short hair-point

Polytrichastrum alpinum (Fig. 2O-Q)

22. Leaves not crowded, distributed throughout the stem; leaves ending in a long, piliferous hair-point

Polytrichum piliferum (Fig. 2R-S)

23. Apical cells hexagonal, rhomboid, linear or somewhat vermicular.

23. Apical cells rounded, elliptic, oblate to short rectangular

24. Leaf border present; laminal cells broad and short, rhomboidal to hexagonal

24. Leaf border always absent, laminal cells oblong, linear-hexagonal or linear or somewhat vermicular

Pohlia cruda (Fig. 2M-N)

25. Leaves reddish and decurrent at the base, apex acuminate, acute to broadly acute, often cuspidate

Bryum pseudotriquetrum (Fig. 2G-H)

25. Leaves greenish to pale brown, never decurrent at the base, apex rounded and obtuse to apiculate

26. Plants whitish due to colorless cells in the apex; apex acute

Bryum argenteum

26. Plants greenish, never whitish; apex obtuse

Bryum orbiculatifolium

27. Margins plane to incurved near the apex; costa homogeneous in cross section

27. Margins recurved to revolute near the apex; costa heterogeneous in cross section Ceratodon purpur.................. 2I-J)

28. Leaves U-shaped in cross section

Schistidium lewis-smithii

28. Leaves keeled to V-shaped in cross section. Schistidium praemorsum (Fig. $2 \mathrm{~T}-\mathrm{V}$ )

Table 1. List of moss families and species collected in Snow Island during Antarctic summers of 2015 and 2018. Classification follows Goffinet et al. (2009). New Occurrences are indicated by an asterisk.

\begin{tabular}{|c|c|}
\hline Families & Species \\
\hline \multirow{2}{*}{ Amblystegiaceae } & Drepanocladus polygamus (Schimp.) Hedenäs * \\
\hline & Sanionia uncianata (Hedw.) Loeske \\
\hline Andreaeaceae & Andreaea regularis Müll. Hal. \\
\hline Bartramiaceae & Bartramia patens Brid. \\
\hline \multirow{2}{*}{ Brachytheciaceae } & Brachythecium austroglareosum (Müll. Hal.) Kindb. * \\
\hline & Brachythecium austrosalebrosum (Müll. Hal.) Kindb. * \\
\hline \multirow{3}{*}{ Bryaceae } & Bryum argenteum var. argenteum Hedw. ${ }^{*}$ \\
\hline & Bryum orbiculatifolium Cardot \& Broth. ${ }^{*}$ \\
\hline & Bryum pseudotriquetrum (Hedw.) G. Gaertn., B. Mey. \& Scherb. * \\
\hline \multirow{2}{*}{ Calliergonaceae } & Warnstorfia fontinaliopsis (Müll. Hal.) Ochyra * \\
\hline & Warnstorfia sarmentosa (Wahlenb.) Hedenäs* \\
\hline \multirow{2}{*}{ Ditrichaceae } & Distichium capillaceum (Hedw.) Bruch \& Schimp. ${ }^{*}$ \\
\hline & Ceratodon purpureus (Hedw.) Brid. * \\
\hline \multirow{2}{*}{ Grimmiaceae } & Schistidium lewis-smithii Ochyra * \\
\hline & Schistidium praemorsum (Müll. Hal.) Herzog * \\
\hline Mniaceae & Pohlia cruda (Hedw.) Lindb. ${ }^{*}$ \\
\hline \multirow{3}{*}{ Polytrichaceae } & Polytrichastrum alpinum (Hedw.) G.L. Sm. \\
\hline & Polytrichum juniperinum Willd. ex Hedw.* \\
\hline & Polytrichum piliferum Hedw. \\
\hline \multirow{4}{*}{ Pottiaceae } & Bryoerythrophyllum recurvirostrum (Hedw.) P.C. Chen * \\
\hline & Syntrichia filaris (Müll. Hal.) R.H. Zander* \\
\hline & Syntrichia magellanica (Mont.) R.H. Zander * \\
\hline & Syntrichia saxicola (Cardot) R.H. Zander* \\
\hline Rhabdoweisiaceae & Hymenoloma grimmiaceum (Müll. Hal.) Ochyra * \\
\hline
\end{tabular}


Table 2. Distribution data of the species present on Snow Island.

\begin{tabular}{|c|}
\hline Species \\
\hline $\begin{array}{c}\text { Drepanocladus polygamus (Schimp.) } \\
\text { Hedenäs }\end{array}$ \\
\hline Sanionia uncianata (Hedw.) Loeske \\
\hline Andreaea regularis Müll. Hal. \\
\hline Bartramia patens Brid. \\
\hline $\begin{array}{l}\text { Brachythecium austroglareosum } \\
\text { (Müll. Hal.) Kindb. }\end{array}$ \\
\hline $\begin{array}{l}\text { Brachythecium austrosalebrosum } \\
\text { (Müll. Hal.) Kindb. }\end{array}$ \\
\hline $\begin{array}{c}\text { Bryum argenteum var. argenteum } \\
\text { Hedw. }\end{array}$ \\
\hline $\begin{array}{c}\text { Bryum orbiculatifolium Cardot \& } \\
\text { Broth. }\end{array}$ \\
\hline
\end{tabular}

Bryum pseudotriquetrum (Hedw.) G. Gaertn., B. Mey. \& Scherb.

Warnstorfia fontinaliopsis (Müll. Hal.) Ochyra

Warnstorfia sarmentosa (Wahlenb.) Hedenäs

Distichium capillaceum (Hedw.) Bruch \& Schimp.

Ceratodon purpureus (Hedw.) Brid.

Schistidium lewis-smithii Ochyra

Schistidium praemorsum (Müll. Hal.) Herzog

Pohlia cruda (Hedw.) Lindb.

Polytrichastrum alpinum (Hedw.) G.L. Sm.

Polytrichum juniperinum Willd. ex Hedw.

Polytrichum piliferum Hedw.

Bryoerythrophyllum recurvirostrum (Hedw.) P.C. Chen

Syntrichia filaris (Müll. Hal.) R.H. Zander

Syntrichia magellanica (Mont.) R.H. Zander

Syntrichia saxicola (Cardot) R.H. Zander

Hymenoloma grimmiaceum (Müll. Hal.) Ochyra
Distribution

few localities in Antarctica. In the South Shetland Archipelago it is cited only for King George and Livingston Islands (Ochyra et al. 2008) and in this study it was found in Snow Island.

Is widely distributed and very common in Antarctica and it had been already reported for Snow Island in President Head Plateau (Ochyra et al. 2008).

Widely distributed in the Antarctic, especially in South Shetland Archipelago and was reported for Snow Island in President Head (Ochyra et al. 2008).

Widely distributed in maritime Antarctica and common in the South Shetland Archipelago. Was reported for Snow Island in President Head (Ochyra et al. 2008).

Widely distributed in Antarctic, including the South Shetland archipelago, but in this region it was only reported in the Livingston and Deception Islands (Ochyra et al. 2008). This species is a new occurrence for Snow Island.

Widely distributed in Antarctica, including in the South Shetland archipelago (Ochyra et al. 2008). This species is a new occurrence for Snow Island.

Widely distributed in Antarctica, but rare in South Shetland Island occurring only in King George and Deception Islands (Ochyra et al. 2008) and now reported for Snow Island.

Has primarily distribution on some volcanic islands in South Sandwich and South Shetland Islands (Ochyra et al. 2008). Considering the South Shetland Archipelago, this species occur in Deception Island (Ochyra et al. 2008) and King George Island (Câmara et al. 2017) and it was reported in Snow Island in the present study.

Is one of the most common species and widely distributed in Antarctica. It is present in South Shetland Archipelago, reported for King George, Livingston, Deception, Nelson and Greenwich Islands (Ochyra et al. 2008) and now it was found in Snow Island.

Is widespread and common in the South Shetland Archipelago where it is reported for the King George, Livingston, Nelson and Robert Islands (Ochyra et al. 2008) but it is not reported for Snow Island until this moment.

Is widely distributed and locally common only in the South Orkney and South Shetland Islands. In the South Shetland Archipelago, this species is reported in several islands (Elephant, King George, Robert and Livingston Islands) but it was not reported for Snow Island (Ochyra et al. 2008).

Is present in several localities of Antarctica. In the South Shetland Islands it is reported to the King George, Livinsgston, Deception and Robert Islands (Ochyra et al. 2008) and now also being reported for Snow Island.

Is widely reported for the South Shetland Islands (Ochyra et al. 2008), however, it had not been cited for Snow Island.

Is endemic from Antarctica and reported only for South Shetlands Archipelago in King George and Livingston Islands (Ochyra et al. 2008; Câmara et al. 2017) and now it is reported to one more island in this archipelago, the Snow Island.

Is known only in three localities in Antarctica. In the West Antarctica Peninsula it is registered in Danco Coast and Fallières Coast and in South Shetlands Archipelago is reported only for Deception Island (Ochyra et al. 2008) and this study found this species in Snow Island too.

Is widely distributed in the South Shetland Islands and in the other localities of maritime Antarctic (Ochyra et al. 2008) but had been not reported yet for Snow Island.

Is widely distributed in maritime Antarctica and present in the Antarctic Peninsula. This species had been already reported to Snow Island in President Head Plateau (Ochyra et al. 2008).

According to Ochyra et al. (2008) this species of more limited occurrence and least common of all species of Polytrichum that occur in Antarctica. This species is locally frequent in tree islands of northern maritime Antarctica (Candlemas and Bellingshausen Islands (South Sandwich Archipelago) and King George Island (South Shetlands Archipelago)). It is scarce elsewhere of South Sandwich Archipelago (Ochyra et al. 2008) and now it is reported for Snow Island too.

Is widely distributed in Antarctica, especially in the South Shetland Archipelago and it is reported to Snow Island in President Head Plateau (Ochyra et al. 2008).

Is widely distributed, but scattered in Antarctica. In South Shetland Archipelago was reported only for Livingston Island (Ochyra et al. 2008), but now it was found in Snow Island.

Is widely distributed in Antarctica and it is most common in South Orkneys and South Shetland Islands, but until this moment this species is not had been reported for Snow Island (Ochyra et al. 2008).

Is present in several regions of Antarctica. In the maritime Antarctica, this species is widely distributed and one of the most frequent species of moss in the South Shetlands Archipelago, but it is not known for Snow Island (Ochyra et al. 2008).

Is widely distributed in South Shetland Island and had not been yet reported for Snow Island (Ochyra et al. 2008).

Is well distributed in several localities of Antarctica including the South Shetland Islands and until this moment it was not reported for Snow Island (Ochyra et al. 2008). 

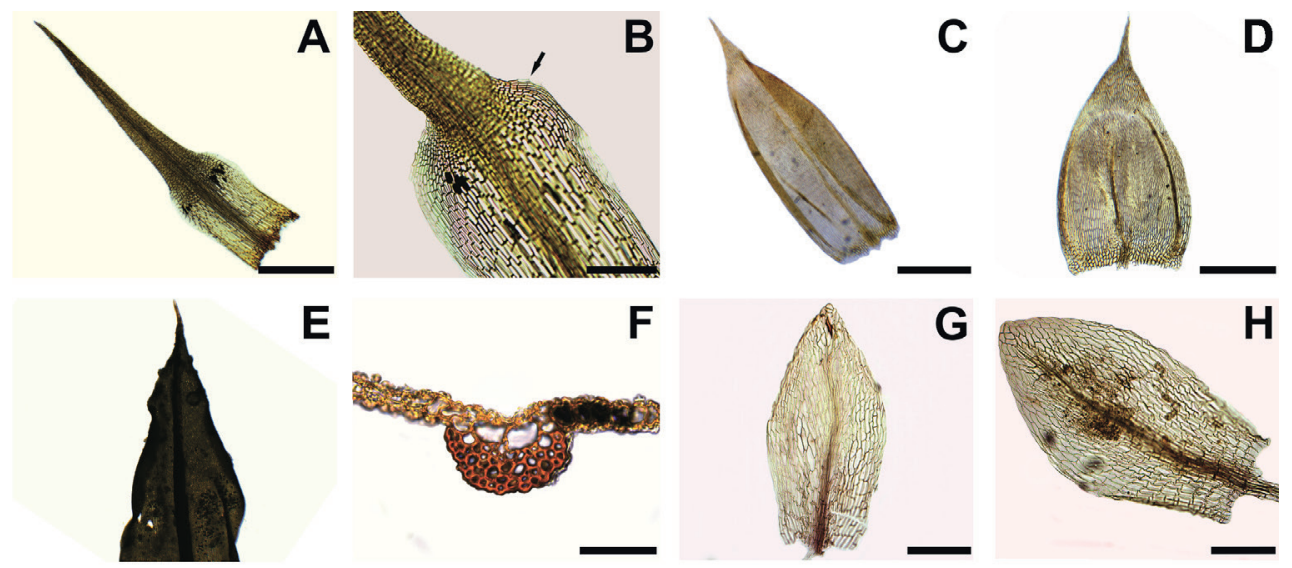

E
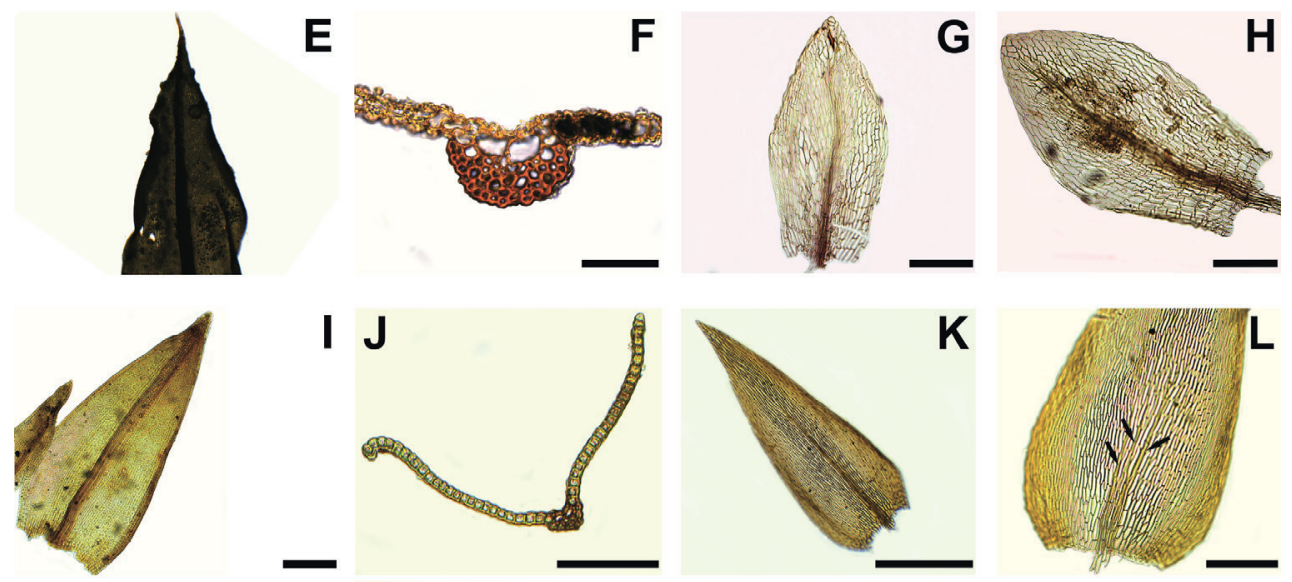

I
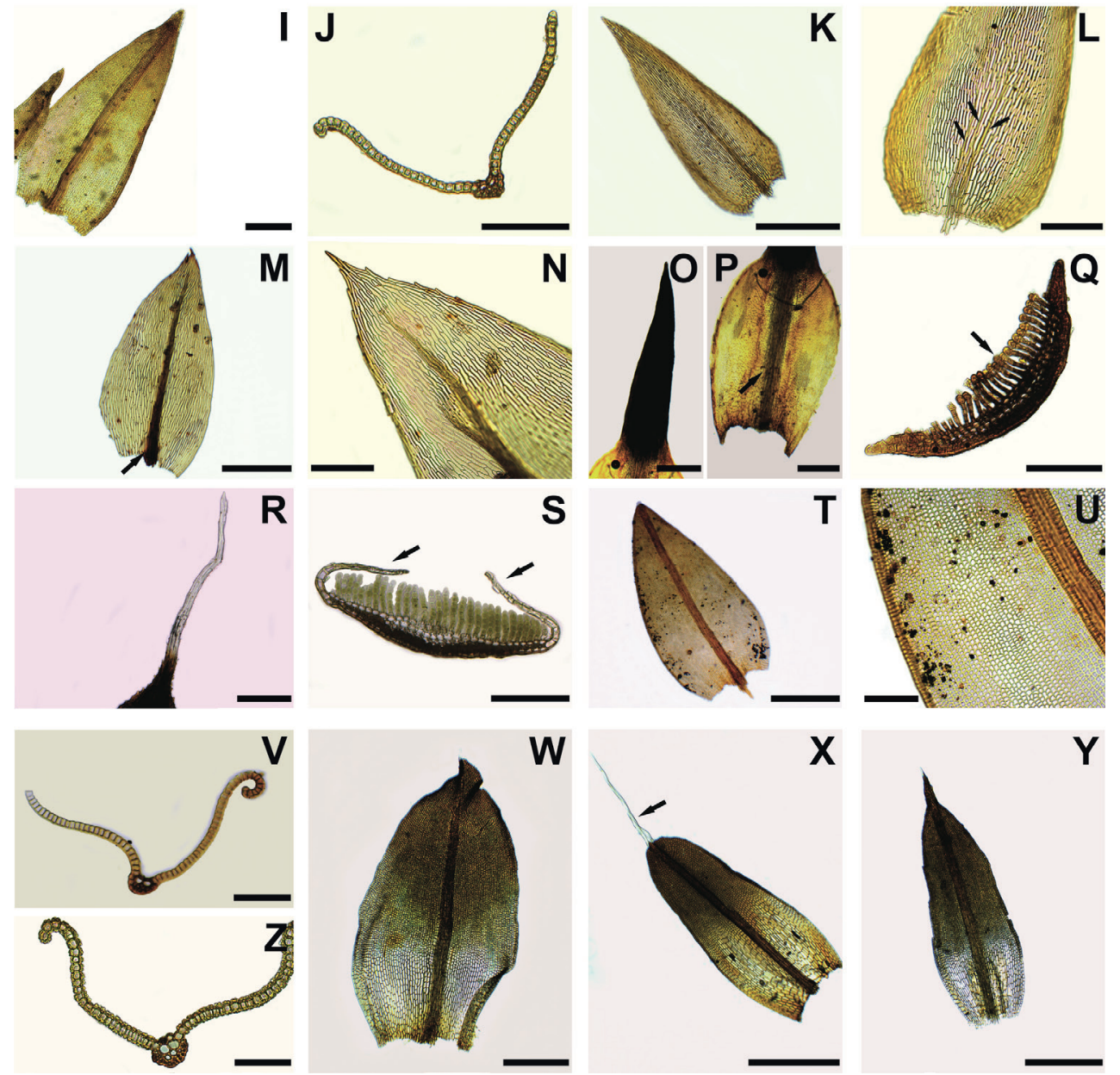

Figure 2. Morphology of some of the mosses occurring on Snow Island. A-B Bartramia patens: A. Leaf, general aspect; B. Detail of shoulder region (arrow). C. Brachythecium austroglareosum: leaf, general aspect; D. Brachythecium austrosalebrosum: leaf, general aspect. E-F Bryoerythrophyllum recurvirostrum: E. General aspect of leaf tip and mid region. F. Transversal section of leaf mid region. G-H: Bryum pseudotriquetrum: G. Branch leaf, general aspect; H. Branch leaf showing variation in shape. I-J: Ceratodon purpureus: I. Leaf, general aspect; J. Transversal section of leaf mid region. K-L: Drepanocladus polygamus: K. Leaf, general aspect; L. Detail of base showing branched costa (arrows). M-N Pohlia cruda: M. Leaf, general aspect; $\mathbf{N}$. Detail of sturdy cells and reddish costa near the base (arrow). O-Q: Polytrichastrum alpinum: O. Detail of apex showing thick costa covering the entire region; $\mathbf{P}$. Detail of leaf base showing slender costa and limb (arrow); Q. Cross section of leaf showing lammellae in a costa (arrow). R-S Polytrichum piliferum: R. Detail of apex bearing long and hyaline awn; $\mathbf{S}$. Transversal section of leaf showing lamellae partially covered by the limb (arrows). T-V Schistidium praemorsum: T. Leaf, general aspect; U. Detail of mid region showing cells with thickened walls; V. Transversal "V-shaped" section of leaf. W. Syntrichia filaris: leaf, general aspect. X, Z: Syntrichia magellanica: $\mathbf{X}$. Leaf, general aspect showing the long and distinctive spurred hyaline awn (arrow); Z. Leaf cross section. Y. Syntrichia saxicola: leaf, general aspect. Scale: A, C, D, E, K, M, O, $\mathbf{P}, \mathbf{T}, \mathbf{W}, \mathbf{X}$ and $\mathbf{Y}=500 \mu \mathrm{m} ; \mathbf{B}, \mathbf{G}, \mathbf{H}, \mathbf{I}, \mathbf{L}, \mathbf{N}, \mathbf{Q}, \mathbf{R}, \mathbf{S}$ and $\mathbf{U}=200 \mu \mathrm{m}: \mathbf{V}$ and $\mathbf{Z}=100 \mu \mathrm{m} ; \mathbf{F}$ and $\mathbf{J}=50 \mu \mathrm{m}$. 


\section{Conclusion}

Mosses are the most abundant plants in Antarctica (Ochyra et al. 2008), unlike other places in the world. Snow Island has high species richness of mosses, representing approximately $26 \%$ of the known diversity of Antarctica, of which about $65 \%$ are new occurrences for the Island found by the present study.

Snow Island has important species of mosses, such as Schistidium lewis-smithii Ochyra, an endemic species of Antarctica, which is now registered for Snow Island. Schistidium praemorsum had been cited for only three localities in Antarctica, but was found on Snow Island by the present study.

The present study increased the knowledge of moss diversity on Snow Island by $190 \%$. This indicates the need and importance for further studies to obtain further knowledge and aid the preservation of local biodiversity.

We believe that the considerable increase in the number of species documented for Snow Island can be explained by climate change, in particular warming in the region. As discussed by Turner et al. (2009), the South Shetland Archipelago is among the regions of Antarctica most affected by the climate. This has been evidenced by other studies, such as Sancho et al. (2017), who revealed changes in the lichen flora, Brabyn et al. (2006). This demonstrates changes in the distribution of moss and algae in Antarctica, in addition to Câmara et al. (2017), Henriques et al. (2018) and Câmara et al. (2020) who showed substantial changes in local floras of the South Shetland Archipelago.

We emphasize the importance of monitoring the local moss flora of Snow Island, due to the establishment of new and rare species. We believe that the creation of a protected area within President Head would be interesting considering the moss flora and the paleobotanical specimens that have been uncovered there.

\section{Acknowledgements}

To the Brazilian Navy and Air Force for logistic support. The authors are also grateful to Bárbara Guedes Costa Silva for helping with the maps. PROANTAR and CNPq (National Council for Scientific and Technological Development) and the Ministry of Science Technology and Innovation (MCTI) for providing funds. The first and second authors thank CAPES (Coordenação de Aperfeiçoamento de Pessoal de Nível Superior) for partial funding of the study.

\section{References}

Amesbury MJ, Roland TP, Royles J, et al. 2017. Widespread biological response to rapid warming on the Antarctic Peninsula. Current Biology 27: 1616-1622.

Anderson LE. 1954. Hoyer's solution as a rapid permanent mounting medium for bryologists. The Bryologist 57: 242-244.
Bargagli R. 2005. Antarctic Ecosystems Environmental Contamination, Climate Change, and Human Impact. Berlin, Springer-Verlag.

Bednarek-Ochyra H, Vana J, Ochyra R, Smith RIL. 2000. The liverwort flora of Antarctica. Krakow, Polish Academy of Sciences.

Biersma EM, Jackson JA, Bracegirdle TJ, Griffiths H, Linse K, Convey P. 2018a. Low genetic variation between South American and Antarctic populations of the bank-forming moss Chorisodontium aciphyllum (Dicranaceae). Polar Biology 41: 599-610.

Biersma EM, Jackson JA, Hyvönen J, et al. 2017. Global biogeographic patterns in bipolar moss species. Royal Society Open Science 4: 170147. doi: 10.1098/rsos.170147

Biersma EM, Jackson JA, Stech M., Griffiths H., Linse K, Convey P. 2018b. Molecular data suggest long-term in situ Antarctic persistence within Antarctica's most speciose plant genus, Schistidium. Frontiers in Ecology Evolution 6: 77. doi: 10.3389/fevo.2018.00077

Bokhorst S, Huiskes A, Convey P, Bodegom PM, Aerts R. 2008. Climate change effects on soil arthropod communities from the Falkland Islands and the Maritime Antarctic. Soil Biology and Biochemistry 40: 1547-1556.

Brabyn L, Beard C, Seppelt RD, Rudolph ED, Turk R, Green TGA. 2006. Quantified vegetation change over 42 years at Cape Hallett, East Antarctica. Antarctic Science 18: 561-572.

Câmara PEAS, Carvalho-Silva M, Henriques DK, et al. 2018. Pylaisiaceae Schimp.(Bryophyta) revisited. Journal of Bryology 40: 251-264.

Câmara PEAS, Silva BGC, Carvalho-Silva M, Henriques DK. 2017. The moss flora of Ostrov Geologov (Geologists Island), Maxwell Bay, King George Island, Antarctica. Boletín de la Sociedad Argentina de Botánica 52: 251-255.

Câmara PEAS, Soares AER, Hernriques DK, et al. 2019a. New insights into the species diversity of Bartramia Hedw. (Bryophyta) in Antarctica from a morpho-molecular approach. Antarctic Science 31: 208-215.

Câmara PEAS, Valente DV, Amorim ET, et al. 2019b. Integrated analysis of intraspecific diversity in the bipolar moss Roaldia revoluta (Mitt.) PEAS Câmara \& M. Carvalho-Silva (Bryophyta) in Antarctica. Polar Biology 42: 485-496.

Câmara PEAS, Valente DV, Sancho LG. 2020. Changes in the moss (Bryophyta) flora in the vicinity of the Spanish Juan Carlos I Station (Livingston island, Antarctica) over three decades. Polar Biology 43: 1745-1752.

Cantrill DJ, Cantrill DJ, Webb JA. 1998. Permineralized pleuromeid lycopsid remains from the early Triassic Arcadia formation, Queensland, Australia. Review of Palaeobotany and Palynology 102: 189-211.

Cantrill DJ. 1997. Hepatophytes from the Early Cretaceous of Alexander Island, Antarctica: systematics and paleoecology. International Journal of Plant Sciences 158: 476-488.

Cassano JJ. 2013. Climate of extremes. In: Walton DWH. (ed.) Antarctica: Global Science from frozen Continent. Cambridge, Cambridge University Press.p. 103-136.

Duane AM. 1996. Palynology of the Byers Group (Late Jurassic-Early Cretaceous) of Livingston and Snow islands, Antarctic Peninsula: its biostratigraphical and palaeoenvironmental significance. Review of Palaeobotany and Palynology 91: 241-281.

Ellis LT, Asthana AK, Gupta R. et al. 2013a. New national and regional bryophyte records, 34. Journal of Bryology 35: 62-70.

Ellis LT, Bednarek-Ochyra H, Ochyra R, et al. 2013b. New national and regional bryophyte records, 35. Journal of bryology 345: 129-139.

Fox AJ, Cooper APR. 1994. Measured properties of the Antarctic ice sheet derived from the SCAR Antarctic digital database. Polar Record 30: 201-206.

Glime JM. 2017. Invertebrates. Bryophyte Ecology, Bryological Interaction. https://digitalcommons.mtu.edu/bryophyte-ecology2/4. 01 Sept. 2020.

Goffinet B, Buck WR, Shaw AJ. 2009. Morphology, anatomy, and classification of the Bryophyta. Bryophyte Biology 2: 55-138.

Henriques DK, Silva BGC, Zuñiga GE, Câmara PEAS. 2018. Contributions to the bryological knowledge of ASPA 125, Fildes Peninsula, King George Island. Biological Research, 51: 29-36.

Hogg ID, Cary SC, Convey P, et al. 2006. Biotic interactions in Antarctic terrestrial ecosystems: Are they a factor? Soil Biology and Biochemistry 38: 3035-3040. 
Lewis-Smith RIL. 1984. Terrestrial Plant Biology of the Sub-Antarctic and Antarctic. Antarctic Ecology 1: 61-162.

Longton RE, Holdgate MW. 1979. The South Sandwich Islands: IV, Botany British Antarct Survey Science. Cambridge, Cambridge University Press.

López-Martínez J, Schmid T, Cañadas ES, Mink S, Nieto A, Guillaso S. 2016. Geomorphology and surface landforms distribution in selected ice-free areas in the South Shetland Islands, northern Antarctic peninsula region. Cuadernos de Investigación Geográfica 42: 435-455.

Magill ER (ed.). 1990. Glossarium Polyglottum Bryologiae. A multilingual glossary for bryology. Monographs in Systematic Botany. Missouri, Missouri Botanical Garden.

Ochyra R, Lewis-Smith RI, Bednarek-Ochyra H. 2008. The illustrated moss flora of Antarctica. Cambridge, Cambridge University Press.

Philippe M, Torres T, Barale G, Thevenard F. 1995. President Head, Snow Island, South Shetland, a key-point for Antarctica Mesozoic palaeobotany. Comptes Rendus-Academie Des Sciences Paris 321: 1055-1062.

Putzke J, Pereira AB. 1990. Mosses of King George Island, Antarctica. Pesquisa Antártica Brasileira 2: 17-71.
Robinson SA, King DH, Bramley-Alves J, et al.2018. Rapid change in East Antarctic terrestrial vegetation in response to regional drying. Nature Climate Change 8: 879-884.

Sancho LG, Pintado A, Navarro F, et al. 2017. Recent warming and cooling in the Antarctic Peninsula region has rapid and large effects on lichen vegetation. Scientific Reports 7: 5689. doi: 10.1038/s41598-01705989-4

Sollman P. 2015. The genus Bryoerythrophyllum (Musci, Pottiaceae) in Antarctica. Polish Botanical Journal 60: 19-25.

Torres T, Barale G, Méon H, Philippe M, Thévenard F. 1997. Cretaceous floras from Snow Island (south Shetland Islands, Antarctica) and their biostratigraphic significance. In: Ricci CA. (ed.) The Antarctic Region: Geological Evolution and Processes. Siena, Terra Antactica Publication. p. 1023-1028.

Turner J, Bindschadler R, Convey P, et al. 2009. Antarctic climate change and the environment. Cambridge, Scientific Committee on Antarctic Research.

Yano O. 1984. Briófitas. In: Fidalgo O, Bononi V. (eds.) Técnicas de Coleta, Preservação e Herborização de Material Botânico. Série Documentos. São Paulo, Instituto de Botânica de São Paulo. p. 27-30. 